\title{
Evaluation of the surface roughness of a nanofilled composite resin submitted to different smoothing and finishing techniques
}

\author{
Avaliação da rugosidade superficial de uma resina nanoparticulada submetida a diferentes técnicas de \\ alisamento e finalização
}

\author{
Micheli Del Frari ANSUJ', Iuri Silveira dos SANTOS ${ }^{a}$, Marcela MARQUEZANa, \\ Letícia Brandão DURAND ${ }^{\text {a }}$, Roselaine Terezinha POZZOBON ${ }^{\text {a* }}$
}

aUFSM - Universidade Federal de Santa Maria, Santa Maria, RS, Brasil

\begin{abstract}
Resumo
Introdução: $\mathrm{O}$ controle da técnica restauradora direta com resina composta no que se refere às características de lisura superficial, é um dos fatores que deve ser considerado para o sucesso restaurador. Objetivo: O propósito deste estudo foi avaliar a rugosidade superficial de uma resina composta nanoparticulada submetida a diferentes técnicas de alisamento e finalização. Material e método: Cinquenta corpos de prova foram confeccionados utilizando a resina composta Z 350 XT (3M ESPE), divididos em cinco grupos sendo: G1 (controle): padrão tira de poliéster; G2: espátula para inserção de resina; G3 pincel limpo com álcool e seco; G4; pincel limpo com álcool, seco e umedecido com adesivo Single Bond (3M ESPE); e, G5: pincel limpo álcool, seco e umedecido com selante de superfície Natural Glaze (DFL). Após a confecção os corpos de prova foram estocados por 24 horas em água deionizada. A rugosidade superficial foi mensurada por meio de um rugosímetro de precisão. As médias foram comparadas por análise de variância, seguida do Teste de Tukey a 5\% de significância. Resultado: A menor rugosidade superficial foi observada em G1 e a maior em G3 O grupo G5, apresentou valores de rugosidade superficial inferiores aos demais grupos testados e próximos ao grupo controle. Conclusão: As técnicas de alisamento e finalização influenciaram a rugosidade superficial da resina composta. O uso de selante resinoso, pela técnica de copolimerização, resultou em menor rugosidade e o emprego do pincel limpo e seco promoveu rugosidade, além do limite aceitável o que pode comprometer o desempenho de restaurações.
\end{abstract}

Descritores: Resinas compostas; materiais dentários; propriedades de superfície.

\begin{abstract}
Introduction: Controlling the surface smoothness characteristics of the composite resin when performing a direct restorative technique is one of the factors involved in achieving restorative success. Objective: The purpose of this study was to evaluate the surface roughness of a nanofilled composite resin submitted to different smoothing and finishing techniques. Material and method: Fifty test specimens were made with the Z350 XT composite resin (3M ESPE) and then divided into five study groups according to the smoothing and finishing method applied, as follows: G1 (control), polyester strip; G2, composite spatula; G3, brush cleaned with absolute alcohol and dried; G4, brush cleaned with absolute alcohol, dried and moistened with Single Bond (3M ESPE); and G5, brush cleaned with absolute alcohol, dried and moistened with Natural Glaze surface sealant (DFL). After fabrication, the specimens were stored for $24 \mathrm{~h}$ in deionized water. The surface roughness of the specimens was measured using a profilometer. Surface roughness means were compared by analysis of variance followed by Tukey's test at a level of significance of 5\%. Result: The lowest surface roughness was observed in G1 (control group) and the highest, in G3. G5 had lower surface roughness values compared to the other test groups, and presented values similar to those of the control group. Conclusion: The smoothing and finishing techniques influenced the surface roughness of the composite resin. Application of the surface sealant by the copolymerization technique resulted in lower roughness values. The use of a clean, dry brush promoted roughness values beyond the acceptable limit, and is therefore liable to compromise the performance of composite resin restorations.
\end{abstract}

Descriptors: Composite resins; dental materials; surface properties. 


\section{INTRODUCTION}

The surface smoothness of a restorative material is an important characteristic that directly influences the longevity of restorations ${ }^{1}$. This property also relates to an increase in wear of restorative materials, accumulation of bacterial biofilm, gingival inflammation and susceptibility to color change by staining ${ }^{2,3}$.

Since its introduction, no material has been as modified and improved as composite resin ${ }^{4}$. The main component of this material, which relates to surface smoothness, is its filler, i.e., the inorganic particles. The factors involved are the type of particle, its size and quantity ${ }^{2}$. Roughness increases with the size of the filler particles and their irregular shape ${ }^{2}$. One of the most important advances in composite resins was the development nanotechnology to obtain filler particles 5 . Smaller particles were produced to improve composite resins without affecting the physical properties of these materials ${ }^{6}$. With this development, there was a reduction in polymerization shrinkage, an increase in strength and elasticity and an improvement in polishing ${ }^{7}$.

Despite all the progress, this material continues to be very sensitive, and the main reason for clinical failure is the application of inappropriate techniques ${ }^{8}$. When adapting, manipulating and smoothing composite resins, clinicians often resort to empiricism and intuition, rather than science, without awareness of the effects of their technical choices.

Various adaptation, smoothing and finishing techniques are recommended when performing direct restorations with composite resins. The use of brushes is recommended for adapting composites, removing minor excesses, reconstructing dental morphology, and obtaining smooth surfaces, with a smooth transition between the resin and the dental substrate, in order to simplify the finishing and polishing steps. Another option for the adaption, smoothing and finishing of composite resins is the use of resin agents applied with a brush ${ }^{9}$. The resin agents available have varied compositions of resin monomers, such as bis-GMA, TEGDMA, THFMA and $\mathrm{UDMA}^{9}$, and were introduced into the market to fill surface defects, maintain surface smoothness, improve resistance to wear $^{10}$ and the marginal integrity of restorations ${ }^{11}$. Two techniques are used to apply resin agents: the conventional technique, in which the resin agent is applied after light-curing of the surface layer of the composite resin and normally after polishing, preceded by acid etching ${ }^{9,12}$; and the copolymerization technique, in which the resin agent is applied directly to the final layer of the composite resin before light-curing 9 . The copolymerization technique is applicable for medium and small Class V, Class I and Class III lingual restorations, in which the shaping and contouring can be obtained before polymerization? In these situations, this technique is recommended as an option to reduce the finishing time required for the restoration.

Recently, the Natural Glaze resin agent (DFL, Rio de Janeiro, RJ, Brazil), classified by the manufacturer as a surface sealant, was introduced into the market. So far, however, there are no studies evaluating its performance either in vitro or in vivo. Along the same line, dental adhesives - which also contain resin monomers and are frequently available for clinical use - could also be used as surface sealing and smoothing agents ${ }^{13}$. In the literature, however, there are no studies evaluating this option. Therefore, based on the context presented, this study's objective was to evaluate the surface roughness of a nanofilled composite resin submitted to different smoothing and finishing techniques in vitro.

Based on the information presented, a null hypothesis was formulated, according to which the smoothing and finishing techniques would have no influence on surface smoothness. An alternative hypothesis was also formulated, according to which the techniques that use a resin agent by means of the copolymerization technique would produce smoother surfaces.

\section{MATERIAL AND METHOD}

\section{Materials}

To conduct this study, the Filtek ${ }^{\mathrm{MR}} \mathrm{Z} 350 \mathrm{XT}$ (3M ESPE, St. Paul, MN, USA) composite resin and the Adper Single Bond ${ }^{\mathrm{TM}}$ 2 (3M ESPE, Sumaré, SP, Brazil) and Natural Glaze (DFL, Rio de Janeiro, RJ, Brazil) resin agents were used to adapt and smooth the composite resin. A description of the materials used in this study is presented in Table 1 .

Table 1. Characteristics of the materials used in the study

\begin{tabular}{|c|c|c|c|}
\hline Material & Classification & Color & Composition (\% of volume)* \\
\hline $\begin{array}{l}\text { Filtek Z350 XT } \\
\qquad(3 \mathrm{M} \text { ESPE) }\end{array}$ & $\begin{array}{l}\text { Nanofilled, photopolymerizable } \\
\text { composite resin }\end{array}$ & $\mathrm{A} 2 \mathrm{E}$ & $\begin{array}{l}\text { Matrix based on bis-GMA, UDMA, TEGDMA, PEGDMA and } \\
\text { bis-EMA; } 55.6 \% \text { of inorganic particles for translucent colors, with a } \\
\text { combination of non-agglomerated/non-aggregated silica filler }(20 \mathrm{~nm}) \text {, } \\
\text { non-agglomerated/non-aggregated zirconia filler (4 to } 11 \mathrm{~nm}) \text { and } \\
\text { aggregated zirconia/silica cluster filler (4 to } 20 \mathrm{~nm}) .\end{array}$ \\
\hline $\begin{array}{l}\text { Adper Single Bond }{ }^{\mathrm{TM}} 2 \\
\quad(3 \mathrm{M} \text { ESPE) }\end{array}$ & Single-bottle adhesive system & - & $\begin{array}{l}\text { Ethanol, bis-GMA, silane treated with silica particles, } 2 \text {-hydroxyethyl } \\
\text { methacylate, glycerol 1, } 3 \text { dimethacrylate, copolymer of acrylic acid } \\
\text { and itaconic acid and diurethane dimethacrylate. } 10 \% \text { of colloidal } \\
\text { silica }(5 \mathrm{~nm}) .\end{array}$ \\
\hline $\begin{array}{l}\text { Natural Glaze } \\
\quad(\mathrm{DFL})\end{array}$ & Surface sealant & - & $\begin{array}{c}\text { Bis-GMA, TEGDMA, 2, } 6 \text { DI, urethane, camphorquinone, benzil } \\
\text { dimethyl ketal, Quantacure EHA. }\end{array}$ \\
\hline
\end{tabular}

${ }^{\star}$ Information provided by the manufacturer. 


\section{Methods}

\section{Preparation of the test specimens}

Fifty disk-shaped test specimens were fabricated, and then divided into five groups $(\mathrm{n}=10)$ according to the composite resin smoothing and finishing technique applied.

A stainless steel split die was used to fabricate the test specimens, with a diameter of $8 \mathrm{~mm}$ and thickness of $2 \mathrm{~mm}$. In all groups, the composite resin was inserted in a single increment and initially adapted in the die with a resin spatula. After this step, the groups were formed according to the smoothing and finishing techniques described in Table 2.

The use of the brush in Groups 3, 4 and 5 was standardized with light strokes and application in all directions. After placement, smoothing and finishing of the composite resin, the test specimens were pre-polymerized for $20 \mathrm{~s}$ with a Blue Fase light-curing unit (Ivoclar Vivadent, Liechtenstein, Germany). A layer of water-soluble liquid glycerin was then applied to the test specimens with a brush to inhibit contact with oxygen, and the resin was light-cured for another $20 \mathrm{~s}$.

\section{Storage conditions}

After fabrication, the test specimens were washed thoroughly with a water and air spray, to remove the glycerin, identified and maintained separately in closed plastic bottles with deionized water in an incubator at $37^{\circ} \mathrm{C}$ for $24 \mathrm{~h}$. After this period, they were submitted to surface roughness readings.

\section{Evaluation of surface roughness}

The quantitative measurement of surface roughness was made using a Mitutoyo Suftest SJ-201P precision roughness tester (Takatsuku, Kawasaki Kanagaua, Japan). The roughness tester was configured to work with an $\mathrm{Ra}(\mu \mathrm{m})$ parameter and cut-off value of $0.25 \mu \mathrm{m}$. Six readings were made of each test specimen, 3 on the $\mathrm{x}$ axis and 3 on the $\mathrm{y}$ axis, from which a roughness mean was obtained for each test specimen of the study groups.

Table 2. Groups and respective surface smoothing and finishing techniques

\begin{tabular}{|c|c|}
\hline Group & Smoothing and finishing technique \\
\hline $\begin{array}{c}\mathrm{G} 1 \\
\text { (Control) }\end{array}$ & Surface with standard polyester strip. \\
\hline G2 & $\begin{array}{l}\text { Adaptation, surface smoothing and finishing with a } \\
\text { spatula appropriate for composite. }\end{array}$ \\
\hline G3 & $\begin{array}{l}\text { Adaptation with a composite spatula, surface } \\
\text { smoothing and finishing with a brush cleaned with } \\
\text { absolute alcohol and dried. }\end{array}$ \\
\hline G4 & $\begin{array}{l}\text { Adaptation with a composite spatula, surface } \\
\text { smoothing and finishing with a brush cleaned with } \\
\text { absolute alcohol, dried and moistened with a drop of } \\
\text { Single Bond } 2 \text { adhesive; copolymerization technique. }\end{array}$ \\
\hline G5 & $\begin{array}{l}\text { Adaptation with a composite spatula, surface } \\
\text { smoothing and finishing with a brush cleaned with } \\
\text { absolute alcohol, dried and moistened with a drop of } \\
\text { Natural Glaze adhesive; copolymerization technique. }\end{array}$ \\
\hline
\end{tabular}

\section{Statistical analysis}

The nominal surface roughness values were tabulated in spreadsheets and analyzed by means of SPSS software (Statistical Package for Social Sciences, version 18.0). Once the normality and homoscedasticity were verified, using respectively the Shapiro-Wilk and Levene tests, the groups were compared with regard to surface roughness by means of analysis of variance (ANOVA) and by the Tukey test, adopting a significance level of 5\%.

\section{RESULT}

ANOVA showed that there were significant differences between the groups studied $(\mathrm{F}=101.847 ; \mathrm{p}<0.05)$. The Tukey test showed significant differences between the group means $(\mathrm{p}<0.05)$, as can be observed by the mean surface roughness values (Ra) and standard deviations (in $\mu \mathrm{m}$ ) presented in Table 3 .

\section{DISCUSSION}

Maintaining a smooth surface is essential to improving the longevity of esthetic restorative materials ${ }^{12}$. Roughness testers have been used for years to measure surface roughness ${ }^{14}$. Surface texture is quantified by means of random readings, in $\mu \mathrm{m}$, and a mean ( $\mathrm{Ra}$, arithmetic roughness) is calculated by group ${ }^{9}$. The arithmetic roughness parameter has been used by many studies to estimate the surface quality of composite resins $s^{2,9,14,15}$, and is well accepted as a characteristic used for the comparison of resin-based materials ${ }^{16,17}$. The present study also used the Ra measurement parameter since it is a representative average of the peaks and valleys of a scan made over a wide area of each test specimen.

The composite resin used in the present study is classified as nanofilled, and is characterized as showing low surface roughness, a material-dependent feature ${ }^{16}$.

According to the literature, a mean surface roughness (Ra) of $0.2 \mu \mathrm{m}$ is the threshold surface roughness for bacterial plaque retention, and a roughness above this value results in biofilm retention and in an increased risk of caries and periodontal disease ${ }^{3}$. Moreover, it is proven that staining is accelerated by an increase in surface roughness ${ }^{15}$. With regard to the results of the present study, only two groups showed values lower than or equal

Table 3. Means and standard deviations (SD) of the surface roughness for each of the study groups (in $\mu \mathrm{m}$ )

\begin{tabular}{cc}
\hline Group & Mean (SD) \\
\hline $\begin{array}{c}\text { G1 } \\
\text { Control })\end{array}$ & $0.071(0.055)^{\mathrm{a}}$ \\
G2 & $0.272(0.054)^{\mathrm{c}}$ \\
G3 & $0.464(0.049)^{\mathrm{d}}$ \\
G4 & $0.322(0.039)^{\mathrm{c}}$ \\
G5 & $0.136(0.045)^{\mathrm{b}}$ \\
\hline
\end{tabular}

Means followed by the same letter do not differ statistically, according to the F test, with a $5 \%$ probability. 
to $0.2 \mu \mathrm{m}$, namely, Groups 1 (control) and 5, in which a surface sealant applied by means of the copolymerization technique was used for smoothing and finishing. This result suggests that this is an option to be used when the polyester strip technique is not recommended, or when performing it is clinically impossible. The Ra values for Groups 2 and 4 were statistically equal, and higher than those of Group 5, albeit within acceptable limits. On the other hand, the roughness obtained by applying the smoothing and finishing technique with a clean and dry brush (Group 3) - a method frequently used in clinical practice --- was twice as high as the acceptable roughness and could negatively influence the performance of esthetic restorations.

In evaluating the $\mathrm{Ra}$ of different smoothing and finishing techniques applied to a nanofilled composite resin, significant differences were observed between the study groups. However, no group was statistically similar to Group 1 (control), in which the surface smoothness was obtained using a polyester strip. This group showed the lowest Ra, accepted as the ideal standard and representative of clinical situations in which these polyester matrices are used ${ }^{14}$. Their use in control groups is reported in numerous studies ${ }^{1,14,18,19}$. The surface smoothness obtained by means of this procedure is due to formation of a surface layer rich in organic matrix ${ }^{2,14}$. However, it is not always possible to use polyester strips to imprint their standard of smoothness on the final layer of a restoration. Thus, other smoothing and finishing techniques are suggested.

Of the smoothing and finishing techniques evaluated in the present study, the one that showed Ra values closest to those of Group 1 was the Group 5 technique, in which a surface sealant was applied by the copolymerization technique. This probably is justified by the composition of this material, rich in resin monomers (bis-GMA and TEGDMA), which are the same components of the organic matrix of composite resins. These monomers probably form a layer rich in organic matrix similar to that obtained when a polyester strip is used, albeit by applying sealant with a brush instead of by exerting pressure with the strip.

No statistically significant differences were observed between the performance of Group 2 - in which the composite resin was placed, smoothed and finished with a spatula - and that of Group 4, in which the smoothing and finishing were performed with Single Bond 2 adhesive by the copolymerization technique. Thus, since the use of the spatula for composite resin alone provided the same result, we feel that there is no point in applying the Single Bond 2 adhesive by the copolymerization technique to the surface of the restoration. Furthermore, by eliminating this step, it is possible to simplify the procedure, save time and reduce costs. In addition, it may also be suggested that the hydrophilic monomers and ethanol present in the composition of Single Bond 2 may promote surface dissolution of the organic matrix. This may have contributed to an increase in roughness values and, consequently, to poorer performance of the group in which the Single Bond $2(\mathrm{Ra}=0.322 \mu \mathrm{m})$ was used, compared to the group in which the Natural Glaze surface sealant $(\mathrm{Ra}=0.136 \mu \mathrm{m})$ was used.

Of the groups tested, the one that showed the highest mean surface roughness was Group $3(\mathrm{Ra}=0.464 \mu \mathrm{m})$, in which the smoothing and finishing were performed with a clean and dry brush alone. In this technique, the bristles of the brush in contact with the non-polymerized composite resin left grooves that explain a mean surface roughness that was significantly higher than that of the other groups, and twice as high as the value recognized as being able to avoid retention of bacterial plaque, namely, $0.2 \mu \mathrm{m}^{3}$. Therefore, using the technique of a clean and dry brush is not a desirable option when a smooth surface is needed.

It should be emphasized that this study initially proposed to evaluate the immediate performance of different smoothing and finishing techniques with regard to mean surface roughness ( $\mathrm{Ra}$ ); however, based on the results obtained here, it would be interesting to evaluate the behavior of these surfaces over time, submitting them to aging processes and to the challenges posed by the oral environment.

\section{CONCLUSION}

The present study demonstrated that the different smoothing and finishing techniques applied to a nanofilled composite resin showed an impact on the mean surface roughness ( $\mathrm{Ra}$ ) of the test specimens. The null hypothesis was therefore rejected.

The technique that used the resin sealant by the copolymerization method produced a surface with less roughness compared to the technique that used the adhesive system or the technique in which only the spatula was used. The alternative hypothesis was therefore partially accepted.

Use of a clean and dry brush produced the greatest surface roughness value, twice as high as the limit considered acceptable, and is therefore liable to compromise the performance of composite restorations.

Studies are warranted to evaluate the effect of aging on the results obtained by the techniques tested in this study, in order to verify whether these results are maintained or altered over time.

\section{REFERENCES}

1. Senawongse P, Pongprueksa P. Surface roughness of nanofill and nanohybrid resin composites after polishing and brushing. J Esthet Restor Dent. 2007;19(5):265-73, discussion 274-5. http://dx.doi.org/10.1111/j.1708-8240.2007.00116.x. PMid:17877626.

2. Marghalani HY. Effect of filler particles on surface roughness of experimental composite series. J Appl Oral Sci. 2010 Jan-Feb;18(1):59-67. http://dx.doi.org/10.1590/S1678-77572010000100011. PMid:20379683.

3. Bollenl CM, Lambrechts P, Quirynen M. Comparison of surface roughness of oral hard materials to the threshold surface roughness for bacterial plaque retention: a review of the literature. Dent Mater. 1997 Jul;13(4):258-69. http://dx.doi.org/10.1016/S0109-5641(97)80038-3. PMid:11696906. 
4. Venturini D, Cenci MS, Demarco FF, Camacho GB, Powers JM. Effect of polishing techniques and time on surface roughness, hardness and microleakage of resin composite restorations. Oper Dent. 2006 Jan-Feb;31(1):11-7. http://dx.doi.org/10.2341/04-155. PMid:16536188.

5. Beun S, Glorieux T, Devaux J, Vreven J, Leloup G. Characterization of nanofilled compared to universal and microfilled composites. Dent Mater. 2007 Jan;23(1):51-9. http://dx.doi.org/10.1016/j.dental.2005.12.003. PMid:16423384.

6. Moraes RR, Ribeiro DS, Klumb MM, Brandt WC, Correr-Sobrinho L, Bueno M. In vitro toothbrushing abrasion of dental resin composites: packable, microhybrid, nanohybrid and microfilled materials. Braz Oral Res. 2008 Apr-Jun;22(2):112-8. http://dx.doi.org/10.1590/S180683242008000200004. PMid:18622479.

7. Ergücü Z, Türkün LS, Aladag A. Color stability of nanocomposites polished with one-step systems. Oper Dent. 2008 Jul-Aug;33(4):413-20. http://dx.doi.org/10.2341/07-107. PMid:18666499.

8. Lopes GC, Vieira LC, Araujo E. Direct composite resin restorations: a review of some clinical procedures to achieve predictable results in posterior teeth. J Esthet Restor Dent. 2004;16(1):19-31, discussion 32. http://dx.doi.org/10.1111/j.1708-8240.2004.tb00446.x. PMid:15259540.

9. Cilli R, de Mattos MC, Honorio HM, Rios D, de Araujo PA, Prakki A. The role of surface sealants in the roughness of composites after a simulated toothbrushing test. J Dent. 2009 Dec;37(12):970-7. http://dx.doi.org/10.1016/j.jdent.2009.08.002. PMid:19686798.

10. Dickinson GL, Leinfelder KF, Mazer RB, Russell CM. Effect of surface penetrating sealant on wear rate of posterior composite resins. J Am Dent Assoc. 1990 Aug;121(2):251-5. http://dx.doi.org/10.14219/jada.archive.1990.0240. PMid:2144862.

11. Bertrand MF, Leforestier E, Muller M, Lupi-Pégurier L, Bolla M. Effect of surface penetrating sealant on surface texture and microhardness of composite resins. J Biomed Mater Res. 2000;53(6):658-63. http://dx.doi.org/10.1002/1097-4636(2000)53:6<658::AID-JBM7>3.0.CO;2-O. PMid:11074424.

12. Santos PH, Pavan S, Suzuki TY, Briso AL, Assunção WG, Sinhoreti MA, et al. Effect of fluid resins on the surface roughness and topography of resin composite restorations analyzed by atomic force microscope. J Mech Behav Biomed Mater. 2011 Apr;4(3):433-9. http://dx.doi. org/10.1016/j.jmbbm.2010.12.004. PMid:21316631.

13. Sadeghi M, Davari A, Lynch CD. The effect of re-bonding using surface sealant or adhesive system on microleakage of class $\mathrm{V}$ resin composite restorations. Dent Res J (Isfahan). 2013 Sep-Oct;10(5):596-601. PMid:24348615.

14. Ergücü Z, Türkün LS. Surface roughness of novel resin composites polished with one-step systems. Oper Dent. 2007 Mar-Apr;32(2):185-92. http://dx.doi.org/10.2341/06-56. PMid:17427829.

15. Lu H, Roeder LB, Lei L, Powers JM. Effect of surface roughness on stain resistance of dental resin composites. J Esthet Restor Dent. 2005;17(2):102-8, discussion 109. http://dx.doi.org/10.1111/j.1708-8240.2005.tb00094.x. PMid:16036126.

16. Han JM, Zhang H, Choe HS, Lin H, Zheng G, Hong G. Abrasive wear and surface roughness of contemporary dental composite resin. Dent Mater J. 2014;33(6):725-32. http://dx.doi.org/10.4012/dmj.2013-339. PMid:25007731.

17. Oliveira GU, Mondelli RF, Rodrigues MC, Franco EB, Ishikiriama SK, Wang L. Impact of filler size and distribution on roughness and wear of composite resin after simulated toothbrushing. J Appl Oral Sci. 2012 Sep-Oct;20(5):510-6. http://dx.doi.org/10.1590/S1678-77572012000500003. PMid:23138735.

18. Janus J, Fauxpoint G, Arntz Y, Pelletier H, Etienne O. Surface roughness and morphology of three nanocomposites after two different polishing treatments by a multitechnique approach. Dent Mater. 2010 May;26(5):416-25. http://dx.doi.org/10.1016/j.dental.2009.09.014. PMid:20097415.

19. Nagem H Fo, D’Azevedo MT, Nagem HD, Marsola FP. Surface roughness of composite resins after finishing and polishing. Braz Dent J. 2003;14(1):37-41. http://dx.doi.org/10.1590/S0103-64402003000100007. PMid:12656463.

\section{CONFLICTS OF INTERESTS}

The authors declare no conflicts of interest.

\section{${ }^{\star}$ CORRESPONDING AUTHOR}

Roselaine Terezinha Pozzobon, Curso de Odontologia, Departamento de Odontologia Restauradora, UFSM - Universidade Federal de Santa Maria, Rua Cesar Trevisan, 1333, 97065-060 Santa Maria - RS, Brasil, e-mail: rpozzobon@uol.com.br 